\title{
Exhibits a number of pieces of apparatus
}

This content has been downloaded from IOPscience. Please scroll down to see the full text. 1910 Trans. Opt. Soc. 12160

(http://iopscience.iop.org/1475-4878/12/1/308)

View the table of contents for this issue, or go to the journal homepage for more

Download details:

IP Address: 142.132.1.147

This content was downloaded on 20/08/2015 at 03:34

Please note that terms and conditions apply. 
DR. W. ET'LLES, F.R.C.S.EdIN., EXHIBITS A NUMBER OF PIECES OF APPARATUS. 8 th June, 1911.

A MAGNETIC scotometer for mapping blind areas in the field of vision-an important aid in the early diagnosis of glauooma-consisted of a baze-covered disc mounted in a vertical plane. By means of a magnet moved over the back of the disc a small polished steel ball was caused to traverse the face or to remain fixed where desired, without any material attachment.

A double pinhole (for Scheiner's test), adjustable as to the distance between the holes, was formed by traversing a pair of slots inclined to one another over a second pair of slots parallel to one another. A modification of the same test suggested by Holth under the name of kinetoscopy was embodied in a machine for rotating a pinhole in a circle of adjustable diameter, and, of course, at such a rate as to secure persistence of vision. The application of this method to determining errors of refraction was fully explained. For rapid retinoscopy, as in the case of examining school children's eyesight, a machine had been invented and was shown by Dr. Ettles, which replaces the trial case, with a very great economy of time. It consists of a full series of trial lenses mounted on leaves that are attached by hinges to a flexible chain hung upon rollers. As each leaf previously hanging free, passes over the upper and smaller roller, it is elected into a vertical position, at right angles to the chain. Thus the successive lenses can be brought into position before the patient's eye very much more quickly than would be possible by any manipulation of an ordinary trial set. The principle of Mangin's mirror was applied to ophthalmoscopy, a plane retinoscope mirror being made virtually a concave mirror by simply clipping a lens from the trial case in front of it. Dr. Ettles' method of examining defects of colour vision by means of comparison spectra was demonstrated and explained. 